\title{
INTERNATIONAL JORDAN EXPEDITION 1966
}

\author{
BY DR. J. MORTON BOYD* \\ The Nature Conservancy, Edinburgh
}

In 1963 and 1965 British expeditions visited the Azraq oasis and surrounding desert in Jordan and reported on the favourability of the area as a Desert National Park and site for an International Biological Station dealing with oasis and desert investigations ${ }^{1}$. This was endorsed by Boyd $^{2}$ and Jaeger ${ }^{3}$. In 1966 the section on Conservation of Terrestrial Communities $(\mathrm{C} / \mathrm{T})$ of the International Biological Programme (IBP) and the Government of Jordan sponsored a third expedition as a final reconnaissance at Azraq for the proposed biological station. Its terms of reference were to explore the range of potentialities for significant research at Azraq with special reference to the various sections of IBP, for it was clear that sections on Productivity of Freshwater Communities, Productivity of Terrestrial Communities, Productivity Processes and Human Adaptability would also be interested. The convener of $\mathrm{IBP} / \mathrm{Cr}$, Mr. E. M. Nicholson, brought together a team of thirteen Austrian, British, Italian and Jordanian scientists from various disciplines to work at Azraq and in Amman between April 20 and May 15.

The two projects proposed at Azraq-the Desert National Park and the International Biological Stationare separate in initial planning, but functionally interdependent. On July 26, 1965, His Majesty King Hussein of Jordan announced his decision to proceed with the park and its research station, and a draft management plan was later written by two officers of the Nature Conservancy ${ }^{4}$. It is now proposed to advance the arrangements for the station ahead of those for the park because the station is also closely related to other scientific developments in Jordan, especially the newly croatiod Faculty of Science in the University of Jordan and the foundation of the Jordanian Academy of Sciences. It was therefore decided that the expedition should concern itself primarily with establishing a scientific programme for the station.

The expedition was at Azraq from April 21 to May 12 On May 13 the members attended a seminar held by the Government of Jordan at the British Council in Amman with Mr. Sami Ayoub, Permanent Secretary of the Ministry of Agriculture, in the chair; at this the work and recommendations of the expedition were outlined to representatives of the Government of Jordan, the University of Jordan and the international aid agencies in the Middle East, under seven headings.

Glimatology (J. A. Davies). The reflexion coefficients for the Azraq basin were calculated from measurements of incoming and reflected solar radiation for dry saline mud, Nitraria bush, reeds, moist grass, tamarisk swamp (flooded), basalt, limestone desert, grass and reeds, flint-covered limestone desert, scrub/sand surface, cracked dry mud, short rush community in shallow water, shallow water, and a field of alfalfa grass.

The reflexion coefficients of the surfaces ranged from 6 per cent (shallow water) to 62 per cent (dry limestonesand desert). The poak value for incoming solar radiation was 1.53 g.cal.cm..$^{-2}$ min..$^{-1}$, which is very high at solar noon. The peak value of reflected radiation was 0.78 g.cal.cm. ${ }^{-2} \mathrm{~min} .^{-1}$, which is more than would be expected from incoming radiation on many days in the United Kingdom.

Routine data were also collected for daily totals of solar radiation, daily maximum and minimum tempera-

* Leader of the expedition. tures, wind run, maximum and minimum humidity, and rainfall.

Hydrology (J. C. Rodda). An investigation was made of the components in the water balance of the Azraq drainage basin $\left(12,800 \mathrm{~km}^{2}\right)$. Records collected over a number of years by the Central Water Authority, as well as those obtained during the expedition, were analysed and a vigil network installed for future investigators of erosion rates. Precipitation amounts recordod at fifteen stations were used to calculate the monthly rainfall for the whole basin, while corresponding evaporation amounts wore estimated by the Penman method, using records from climatological stations at Azraq and $H 5$. Discharges from the pools at Azraq Shishan and Azraq Druz were assessed from the records of flow over tho weirs that had been installed at those sites, together with the records of the quantities of water pumped to Irbid from Druz. Analyses of water samples taken each fortnight at the pools showed that this pumping had not affected the quality of the water. Records of water table lovels were not obtained, but relations between the magnitude and frequency of heavy falls of rain were calculated for several sites as a guide to how often infiltration might take place.

Water samples were taken from the pools for dating the entry of water into the aquifer by tritium counting and carbon-14 analysis.

Hydrobiology (H. Löffler and G. Bonomi). Some thirty-one different water bodies were sampled throughout tho Azraq basin. Values for conductivity, $p \mathrm{H}$, alkalinity and total hardness were obtained and other analyses were later carried out in Austria and Italy. Samples of plankton and standing crop of invertebrates were also obtained at most of these sites, which included various parts of the freshwater and saline marshes, the playas, wells and seasonal pools in the desert.

Productivity sampling was carried out in Druz Lake, the tamarisk swamp and Ain Soda with the carbon-14 technique. Each site was sampled twice over full daylight periods and the samples were taken to Vienna for final analysis. Simultaneous determinations of oxygen and thermal records by thermistor and thermograph were made.

The situation in the oasis is strongly characterized by a gradient in salinity towards the centre of the area which is situated in Qa el Azraq; high values of alkalinity wero also recorded, especially in Druz Lake where a value of 50 m.equiv. was obtained. The most remarkable feature of the standing crop of invertebrates was the dense concentration of molluses and amphipods in the permanent pools wheroas the periodic lakes tend to be settled by Phyllopoda and Anostraca as well as Rotifera such as Brachionus. Primary production and standing crop in the Qa from flooding to drying out would be an interesting initial investigation at Azraq.

Entomology (D. S. Fletcher). Stations in the Shishan and Druz marshes, in the wadis Ratam, Aseimir (at Qasr Amra), Shaumari (at the Experimental Station), Aseikhim and Rajil, at Faidhat edh Dhahikiya, in the basalt desert between Shishan and Druz, at El Hammad,

Table 1. Maximum Rainfali (mm) LIKELY to OCCUR IN ONE DAY FOR a

$\begin{array}{cccc} & \text { GIVEN RETURN PERIOD } \\ \text { Site } & 10 \text { year } & 20 \text { year } & 50 \text { year } \\ \text { Um El Quttein } & 39 & 45 & 53 \\ \text { Azraq } & 29 & 35 & 42 \\ H 5 & 26 & 31 & 37\end{array}$




\section{Sorry, for copyright reasons some images on this page may not be available online}

\footnotetext{
Fig. 1. Aerial photograph of the Azraq Oasis showing the mosaic of wetland vegetation with peculiar "islands" of dry Nitraria salt flat. In the background is the village of Azraq Shishan, the open limestone desert and, in the upper le $t$, a stretch of basalt desert. (Photo by E. Hosking.)
}

along the trans-Arabian pipeline, in the basalt district of Aseikhim and in the hammada desert adjacent to Shishan were visited for general day collecting; many of the stations were also light-trapped at night, with oither a mercury-vapour or paraffin pressure lamp. Pitfall traps were used in the Shishan marsh and in the hammada desert.

The collection suggests that the Lepidoptera are limited to comparatively few species, but that these are present in abundance. Among the Macrolepidoptera there appears to be a strong migratory element with Leucania vitellina, Heliothis armigera, Agrotis ipsilon, Spodcptera єxigua and Nomophila noctuella prominent. The ratio of specimens to species noted in the Lepidoptera appears also to apply to the Hymenoptera and Odonata; there seem to be five or six species of the latter in the rich marsh vegetation.

Ornithology (I. J. Ferguson-Lees, J.S. Ash, R. Spencer, D. I. M. Wallace and S. Cramp). Many ornithological habitats investigated in 1965 were re-examined in 1966. A.t the oasis these included transects in Arundo, Typha, Tamarix, Scirpus, Juncus, mud-flats at the edge of the open water, etc., as well as in the adjacent Nitraria zones and silt-dunes and the village communities of Druz and Shishan. Desert transects included a wide variety of wadis, ranging from those with little shrublet cover through ones with denser and higher shrubs to the Retama and Pistacea wadis, and sample areas of the limestone hammada, the basalt and the chalk cliffs of Faidhat edh Dhahikiya. The proportionate numbers of about ten of the breeding species were rather different compared with 1965 ; it is possible that this is correlated with differential winter rainfall and subsequent vegetation growth.

More than 2,500 birds of fifty-five species, mostly migrants, were trapped, ringed, weighed, wing-measured and released. Some of these were re-trapped at least once. These data are still being analysed, but they and field observations provided further information on the length of time migrants stay at Azraq, on their physical condition and on their ability to replace fat deposits lost on migration. More than 200 measurements were made of the weights of Riparia riparia, Hirundo rustica, Motacilla flava, Anthus cervinus and Sylvia curruca.

In the period mid-April to mid-May nearly 230 species of birds have been recorded in the Azraq depression. About sixty of these breed, of which about half are primarily desert forms and the rest are centred on the oasis. A fow of the breeding species also occur as migrants and so the total of migrant species is about 185. Some of these occurin thousands and it is cloar that Azraq is an important staging post for migrants. Recoveries of Hirundo rustica. and Jynx torquilla $1,920 \mathrm{~km}$ and $2,130 \mathrm{~km}$ N.N.W. in Russia only 14 and 16 days after ringing have added to the knowledge of the populations involved (FergusonLees ${ }^{5}$.

With regard to conservation it is particularly important to assess the significance of the oasis to wintering wildfowl and for this a mid-winter visit by ornithologists will be necessary.

Mammalogy (S. I. Atallah). Daily trapping of mammals was achieved with break-back traps and other methods in cultivated land around Shishan and Druz villages, three wadi systems, basalt and hammada desert, Nitraria zone, loose sand and chalk cliffs. Jerboas were collected at night in various flint desert localities and in a chalk wadi, while bats were collected at Qasr el Azraq, Faidhat edh Dhahikiya chalk cliffs and Shishan village.

Twenty-two mammals were recorded: Crocidura russula, Suncus etruscus, Paraechinua aethiopicus, Pipistrellus kuhli, Otonycteris hemprichi, Tadarida teniotis, Vulpes vulpes, Hyaena hyaena, Felis silvestris, Gazella gazella (captive), Lepus arabicus, Eliomys melanurus, Jaculus jaculus, Allactaga williamsi, Mus musculus, Acomys russatus (new subsp.), Gerbillus dasyrus, G. henleyi (new subsp.), Meriones tristrami, $M$. libycus, $M$. crassus, Psammomys obesus.

The commonest and most widespread species is Meriones libycus; it is highly colonial and the same ground is shared with $M$. crassus and Psammomys obesus. Gerbillus dasyrus also seems to use the burrows of $M$. libycus; the best. example of this was in an area south of Shaumari experimental station where it was estimated that, 2,000 rodents were present in $2 \mathrm{~km}^{2}$ of wadi system. A common mammal in the flint desert is the jerboa Jaculus jaculus which occurs with Lepus arabicus and Vulpes vulpes. The bats collected were all forms asscciated with cultivation and may have been on migration; no desort forms were found.

A large number of reptiles and amphibians was also collected, representing some seventeen different species. The following is a list of those already identified: Rann ridibunda, Hemidactylus turicus, Piyodactylus hasselquisti, Agama ruderata pallida, A. sinaita, Varanus griseus, Chalcides ocellatus, Mabuia vittata, Acanthodactylus pardalis, A. scutellatus, Natrix tesselata, Coluber rogersi, Malpolon moilensis, M. monspessulana and Ophisops sp. 
Human Ecology (E. Sunderland). An attempt was made to examine the adaptability of the people of Shishan and Druz and ultimately the Bedouin to the dry, hot desert environment. The first step was to obtain a measure of the heterogeneity of each community in terms of colour blindness, fingerprinting, height/weight ratios, skin colour and blood grouping.

The pedigrees of thirty-two families in Shishan and eighty-three in Druz were recorded. The bloods were grouped for the antigens $\mathrm{A}, \mathrm{B}$ and $\mathrm{O}, \mathrm{C}, \mathrm{c}, \mathrm{D}, \mathrm{E}, \mathrm{e}, \mathrm{M}, \mathrm{N}$, $\mathbf{S}, \mathbf{s}, \mathrm{K}, \mathrm{k}, \mathrm{P}$ and $\mathrm{Fy}$. These analyses together with examinations of blood smears for sickle cells were done at the Anthropological Blood-Grouping Laboratory in Beirut. Azraq Shishan contains 229 people living in thirty-eight households and Azraq Druz contains some 1,075 individuals in about 120 households. The data obtained serve to establish some basie genetic "quantities" for the Azraq villagers, but far more work along these and other medico-genetic and social lines could be and should be conducted here.

Follow-up. On the basis of this preliminary report the expedition has made its recommendations in a project paper for an International Biological Station at Azraq to the CT Soctional Committee. In this article the potentialities for future biological research at Azraq are described under the various disciplines together with a section on the constitution and finance of the station.

\footnotetext{
1 Mountfort, G., Portrait of a Desert (Collins, London, 1965).

${ }^{2}$ Boyd; J. M., Nuffield Travelling Fellowship Report (Nature Conservancy, London, 1965).

3 Jaeger, J., jun., Report to USAID Jordan (Amman, 1965).

${ }^{4}$ Hemsley, J. H., and George, M., Azraq Desert National Park, Jordan; Draft Management Plan (Nature Conservancy, London, 1966). Ferguson-Lees, I. J., "Wryneck's Rapid Journey after Off-passage Recupera-
tion", Bird Study (September, 1966).
}

\title{
CANCER RESEARCH
}

\begin{abstract}
The 700-page 43rd Annual Report of the British Empire Cancer Campaign for Research for 1965 describes the investigations financed by the Campaign or carried on at institutions working in association with it. The subject matter of the book can be divided into three parts which are dealt with separately in what follows.
\end{abstract}

\section{Carcinogenesis and the Biology of Cancer Generally}

Tнове who are engaged in some different field, and even some who are in cancer research, may not perhaps appreciate that the work of Doll and Hill (1950) on the relationship between cigarette smoking and lung cancer, and that of Gross (1951) in the United States on mouse leukaemia virus, represent the outstanding achievements of the past 16 years. These two themes-environmental factors and virus-and also immunology, malignant transformation in vitro and experimental carcinogenesis are the most interesting features of cancer research today. The report of the British Empire Cancer Campaign contains numerous references to DNA, but this lies on the sidelines and in more academic spheres. Among the accounts which it contains of the hundreds of investigations on all aspects of cancer research, some are highly condensed, and others read more like laboratory note-books, as though some kind of justification of grants is required.

The reader embarking on the report proper can find a little light relief from, first, an example of the intimidating technicalities used by scientists when they write about their special branches of research. Thus Hambly, at Cambridge: "Relation of Linkage Group VII to Lung Tumour Susceptibility in the Mouse. A six generation breeding programme is under way to reconstitute the linkage Group VII chromosome wavy-2, tumour susceptibility and vestigial tail, using a stock of $w a_{2}+{ }^{T m} v t /+{ }^{w a 2} T m+{ }^{v t}$ isogenic with strain A/Cam. This has reached the third generation. It should yield, during the first half of 1966 , some useful data on the relationships between tumour susceptibility and the markers $w a_{2}$ and $v t$ '. Second, there is a fine example of scientific ultra-caution: Green at Leeds commenting on his interpretation of carcinogenesis as the result of immune reaction writes, "One of the factors which might contribute to the overall activity of a carcinogen is the ability to suppress the host's immune defences (Berenbaum, 1964). The results of a small experiment by Mr. Westrop tended to support this view but, in keeping with most of the attempts which have sought to evaluate the role of the immunological mechanism in carcinogenesis, it hints that many variables, such as sex and age of the animals and the scheme of carcinogen treatment, have a decisive influence on the final observations especially if the latter are of the all-or-none variety", and "Whatever the exact interpretation of the results is, it would seem that the rat subcutaneous tissues may have been sensitized by the oral dose of DMBA. An explanation in terms of immune processes seems most likely, though one cannot exclude a summation of the orally ingested compound and that given remotely. This latter explanation, however, does not seem likely". Third, there are some airy pronouncements by Burch of Leeds in his theoretical treatment of the problem of carcinogenesis: "... spontaneous and induced gene mutation leading to disturbed-tolerance auto-immune and malignant disease in mammals probably entails not point-type mutation (such as base transition, transversion or deletion) but a switch in messenger RNA transcription from the regular strand of DNA ... over to the base-paired complementary anti-parallel strand of the same structural gene (Burch and Burwell, 1965). This theory is capable of solving the long-standing paradox concerning the crosssection of mammalian genes for radiogenic mutation. 'The mutagenic event probably blocks messenger RNA transcription from the normal strand of DNA, removes a DNA-strand-determining polypeptide chain from the minor groove of the double helix, and thus allows transcription to occur from the anti-parallel strand of DNA".

At the Middlesex Hospital the study continues, by tissue culture and electron microscopy, of Burkitt's lymphoma found in young negroes in Uganda. The tumour is probably caused by a virus which may either be specific to it or carried preferentially as an unknown passenger; passage to monkeys results in cystic bone changes and the appearance of sheets of lymphoblastic tumour cells. (See also the reference to Burkitt in the third section of this review.)

Alexander and his colleagues are working on the treatment of animal tumours by immunological methods, and find that tumour inhibition can be achieved in transplantable sarcoma in rats induced by benzpyrene if they are injected with lymphocytes from rats which have been immunized with the same tumour material; the lymphocytes must act indirectly, for radioactive labelling shows that they collect in the spleen and not in the tumour undergoing treatment. The lymphocytes from the immunized rats can be replaced by lymphocytes from immune sheep provided that massive doses $\left(10^{9}\right)$ of cells are used and immune horse lymphocytes are also effective; it is concluded that anti-tumour action relies on the specific antigens which are individual to each tumour. 